\title{
Seedling Performance of Cocoa Genotypes (Theobroma cacao L.) in Drought Stress Condition
}

\author{
Agung Wahyu Susilo ${ }^{(*)}$, Adinda Wuriandani ${ }^{2)}$, Sobir $^{2)}$ and Desta Wirnas ${ }^{2)}$ \\ ${ }^{1)}$ Indonesian Coffee and Cocoa Research Institute, J1. PB. Sudirman 90, Jember, Indonesia \\ ${ }^{2)}$ Plant Breeding and Biotechnology, Department of Agronomy and Horticulture, IPB University, Bogor, Indonesia \\ ${ }^{*}$ Corresponding author: soesiloiccri@yahoo.com \\ Recived: 17 October 2019 / Accepted: 6 November 2019
}

\begin{abstract}
Drought stress can affect changes in physiological, morphological, biochemical, and molecular of plant. Plant in drought stress showed slower growth and development than in normal condition. This research aimed to determine the response of cocoa genotypes in seedling phase to drought stress in morphological and stomata character. This research conducted with split-plot design with main plot were water regimes (25\% and $100 \%$ available water content). Eleven genotypes were used in this research consisted of six genotypes crosses and five genotypes parents. Variables observed were stem diameter, root volume, root length, leaf area, shoot fresh weight, root fresh weight, shoot dry weight, root dry weight, root/shoot ratio, and stomatal conductance. Drought stress decreased values associated with all observed morphological characters and stomata characters. Root/shoot ratio and stomatal conductance can be used to determine genotype with tolerance to drought. Sulawesi 3 x ICCRI 09 showed heighest in root/shoot ratio and stomatal conductance. Sulawesi 3 x ICCRI 09 can be used as candidate of plant material tolerant to drought.
\end{abstract}

Keywords: Theobroma cocoa, genotype, drought stress, growth, seedling

\section{INTRODUCTION}

Cocoa is one of the leading agriculture or industrial crops in Indonesia. Indonesia is the third largest cocoa producer in the world after Ivory Coast and Ghana (ICCO, 2017). Cocoa production in Indonesia in the last five years has decreased by 32 thousand tons (Ditjenbun, 2017). One factor that causes low cocoa production is abiotic factors such as drought stress (Alban et al., 2016). According to Bunn et al. (2017), climate change in Indonesia like drought condition can cause decrease in yield at center production of cocoa in 2050 (see also Ojo \& Sadiq, 2010). Drought condition can affect cocoa performance in seedling phase or in mature plant.
Drought stress can changes physiology, morphology, biochemistry and molecular of plants. Drought stress occurred when water availability in soil decrease due to low soil moisture at certain period of time. Water deficiency in plants occurred when transpiration is higher than water taken by the roots (Salehi-Lisar \& Bakhshayeshan-Agdam, 2016).

Several studies in drought stress have been carried out, especially on cocoa crops. Drought stress research in cocoa plants is carried out in the seedling phase referred to Alban et al. (2015), Santos et al. (2016), Alban et al. (2016), Ayegboyin \& Akinrinde (2016), Setyawan et al. (2018), and Zakariyya \& Indradewa (2018). Seedling phase is a critical 
phase of plants in drought stress conditions (Azzeme et al., 2016). In the seedling phase, plants need large amounts of water for growth and development activities.

Cocoa plants in drought stress will have a shorter shape and smaller stem diameter than normal plants (Ayegboyin \& Akinrinde, 2016). Drought stress conditions not only affected by reducing leaf size, but also reducing the number of leaves per plant (Santos et al., 2016). Good root growth shows the mechanism of the plant to absorb water and nutrients in the soil. Drought stress condition can significantly reduce the dry weight of roots and shoot of cocoa plants. This condition causes decreasing of root/shoot ratio in plants (Santos et al., 2016; Setyawan et al., 2018). Drought condition also reduce stomatal conductance. Stomatal conductance has important role in $\mathrm{CO}_{2}$ uptake and water loss through transpiration (Zakariyya \& Indradewa, 2018).

One effort to overcome the effects of drought stress on cocoa is development of superior clones and drought tolerant cocoa hybrids. Wuriandani et al. (2019) have already crossing cocoa parent materials to produce superior genotypes and cocoa clone tolerant to drought condition. Superior genotype from crossing can be used for planting material in drought condition. This efforts are carried out to maintain decreasing cocoa productivity caused by drought stress. Development of drought resistant cocoa genotypes can be done through selection in morphological and stomata characters (Medina \& Laliberte, 2017).

Aims of this research were to obtain response of drought stress condition in F1 genotypes. The best $\mathrm{F} 1$ performance in drought stress condition could be used as planting material or genetic material for crossing.

\section{MATERIALS AND METHODS}

This research was conducted at Kaliwining Experimental Station, Indonesian Coffee and
Cocoa Research Institute from August 2018 until May 2019. Planting activity after crossing and produced $\mathrm{F} 1$ genotypes were carried out at a greenhouse of Kaliwining Experimental Station, Indonesian Coffee and Cocoa Research Institute, Jember, Indonesia.

Eleven planting materials (F1 and Halfsib of parental genotypes) were used in this research consisted of KW 516 x ICCRI 09, KW 516 x Scavina 6, Sulawesi 3 x ICCRI 09, Sulawesi 3 x Scavina 6, TSH 858 x ICCRI 09, TSH 858 $\mathrm{x}$ Scavina 6 as $\mathrm{F} 1$ genotypes. Halfsib parental genotypes consisted of KW 516, ICCRI 09, Scavina 6, Sulawesi 3, and TSH 858. KW 516 was classified as drought tolerant clone (Zakaryya et al., 2017), while Sulawesi 3 and Scavina 6 as moderate clones (Towaha \& Wardiana, 2014), and TSH 858 as susceptible clone (Iriyono, 2010; Kurniawan, 2017)

Soil analysis used the $\mathrm{pF}$ curve to determine the permanent wilt point and field capacity of the land used in first research preparation. Drought stress treatment was given to plants at 1.5 months old (6 week after showing). Drought treatments consisted of $100 \%$ and $25 \%$ available water content. The plants were maintained without water for 5 days to modulate the drought intensity.

Observations were made on plant morphological characters such as: plant height, number of leaf, stem diameter, leaf area, stomatal conductance, root length, root volume, shoot fresh and dry weight, root fresh and dry weight, and root/shoot ratio. This observation was finished at four months old (16 weeks after showing). This research conducted with split-plot design with main plot were water regimes $(25 \%$ and $100 \%$ available water content) while the sub plot were 11 genotypes used in this research. Linear additive models was:

$$
Y_{i j k}=\mu+\alpha_{i}+\beta_{j}+(\alpha \beta)_{i j}+\gamma_{k}+\alpha \gamma_{i k}+\varepsilon_{i j k}
$$

Yijk = observation value $\mathrm{i}$ on water regimen, replication $\mathrm{j}$, and genotype $\mathrm{k}$

$\mu \quad=$ overall data mean $\mathrm{Y}$ 


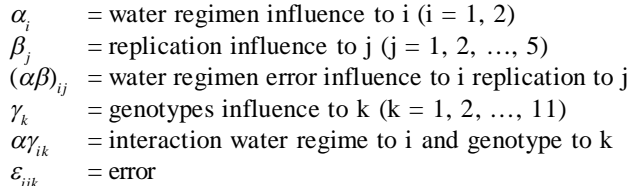

Duncan's multiple range test (DMRT) as Post-hoc test was used if there was any significant difference between treatments with $95 \%$ confidence level. Correlation between characters were analyzed by Pearson correlation analysis. Coefficient correlations value was conducted based on Singh \& Chaudhary (1985):

$$
r g_{x y}=\frac{\operatorname{cov} g_{x y}}{\sqrt{\sigma^{2} g_{x} \cdot \sigma^{2} g_{y}}}
$$

$\mathrm{rg}_{\mathrm{xy}} \quad=$ genetic correlation between $\mathrm{x}$ and $\mathrm{y}$

$\operatorname{cov} g_{\mathrm{xy}}=$ genetic covariance between $\mathrm{x}$ and $\mathrm{y}$

$\mathrm{o}^{2} \mathrm{~g}_{\mathrm{x}} \quad=$ genetic variance $\mathrm{x}$

$\sigma^{2} g_{y} \quad=$ genetic variance $y$

\section{RESULTS AND DISCUSSION}

Genotype and water regimen had significantly different performance for all observed characters. Interaction both of factors had significantly differences for all observed characters. This results showed decreasing of character values in drought stress condition except root length and root/shoot ratio (Table 1, Table 2). Drought stress in cocoa plant affected slower of growth than normal plant (Ayegboyin \& Akinrinde, 2016; Santos et al., 2016; Alban et al., 2016). Plants need enough water for metabolism activity (Sobir et al., 2018), especially in seedling phase (Maynard \& Orcott, 1987).

Plant in drought stress condition showed slow high increment of plant height than normal plant (Figure 1j). This result related to other research which showed slow height increment than normal plant condition (Alban et al., 2016). TSH 858 x ICCRI 09 showed the same performance of growth between normal and drought condition (Figure 1). Plant height at drought condition was higher than normal at 5 WAS (weeks after sowing). Plant height in normal condition showed increasing value at 9 WAS (Figure $1 \mathrm{j}$ ). This result implied slow response to drought condition for genotype TSH 858 x ICCRI 09. Drought stress was influence at 9 WAS-16 WAS.

Drought stress condition affected by decreasing total number of leaves. Refer to Santos et al. (2016), plants in drought conditions will reduce total number of leaves in order to maintain the availability of water in plants, reduce transpiration and metabolism activity for plant tissue maintain. This result showed that drought condition affected slow increasing number of leaves until 16 WAS for all observed genotype (Figure 2). This result indicated slow increasing total number of leaves to reduce transpiration rate.

According to this result, mean value of stem diameter and leaf area in drought stress condition were lower than normal condition (Table 1). Zakariyya \& Indradewa (2018) reported that drought stress condition influence reduction of vegetative stage in cocoa. In drought condition, all of observed genotype did not show significant differences in stem diameter character. KW 516, ICCRI 09, and TSH 858 as parents showed high value of stem diameter $0.55 \mathrm{~cm}, 0.53 \mathrm{~cm}$, and $0.52 \mathrm{~cm}$ respectively. The high value of stem diameter in F1 genotypes were showed in KW 516 x ICCRI 09, Sulawesi 3 x ICCRI 09, and TSH 858 x Scavina $6(0.50 \mathrm{~cm}, 0.49 \mathrm{~cm}$, and $0.53 \mathrm{~cm}$ ) respectively (Table 1 ).

Drought stress decrease leaf cell area and directly decrease leaf area (Ayegboyin $\&$ Akinrinde, 2016). The highest leaf area was found in normal condition. In drought condition, ICCRI 09 as parent showed highest value $\left(70.75 \mathrm{~cm}^{2}\right)$ and Sulawesi $3 \mathrm{x}$ ICCRI 09 as F1 genotype showed highest value $\left(70.47 \mathrm{~cm}^{2}\right)$. This value did not show significant differences with the other genotypes (Table 1). Drought stress in cocoa plant also affect closing of stomata and inhibit of photosynthesis (Pirasteh-Anosheh et al., 2016; Zakariyya \& Indradewa, 2018). 
Stomatal conductance did not show significant differences between drought and normal condition and indicated ability of drought stress tolerance. This result indicate the ability of genotype in drought stress to maintain metabolism activity. Sulawesi 3 x ICCRI 09 and TSH 858 x ICCRI 09 as F1 genotypes did not show significant differences between normal and drought stress in width of stomata opening. The value was drought and normal respectively $0.96 \mu \mathrm{m}$ and $1.04 \mu \mathrm{m}$ for Sulawesi 3 $\mathrm{x}$ ICCRI 09 and $0.86 \mu \mathrm{m}$ and $0.96 \mu \mathrm{m}$ for TSH 858 x ICCRI 09 (Table 1).

Elite cocoa seedling is determined by morphological of root system which consisted of stem diameter, root volume, and root area (Setyawan et al., 2018). Root length of Sulawesi 3 x ICCRI 09 in drought stress condition showed the highest value than normal condition $18.41 \mathrm{~cm}$ (Table 1). Good root development will support plant growth, biomass development, and drought stress tolerant ability. Root will response drought condition through elongation of root to access water. Root growth in Sulawesi 3 x ICCRI 09 could be used as drought tolerant candidate because this genotype had good root growth in drought condition.

Drought stress affects in biomass formation of plant. Biomass in drought stress has lower value than normal condition (Alban et al., 2016; Santos et al., 2014; Santos et al., 2016). Low values of root and shoot dry weight and root and shoot fresh weight in drought than normal condition for all genotypes were found (Table 2). Low value of biomass influence root/shoot ratio (Alban et al., 2016; Santos et al., 2016). Refer to Beets et al. (2007) high value of root/shoot ratio was good for seedling phase. Sulawesi $3 \times$ ICCRI 09 and TSH 858 x Scavina 6 had the highest value of dry weight of root than all F1 genotypes $(0.72 \mathrm{~g}$ and $0.84 \mathrm{~g})$. Refer to Setyawan et al. (2018) high value of root weight will increase of root/shoot ratio. Sulawesi 3 x ICCRI 09 had high value in root/shoot ratio (0.43). This value did not significantly difference with ICCRI 09, Scavina 6, Sulawesi 3, and Sulawesi 3 x Scavina 6 (Table 2). Tolerant genotype of cocoa in drought stress had high value root/shoot ratio. This result indicated tolerant genotype will maintain of root growth like in normal condition (Santos et al., 2014; Santos et al., 2016).

Leaf area character showed positive and significant correlation to all characters except stem diameter, total number of leaf, root length, and root/shoot ratio. Stomatal conductance had significant and positive correlation to leaf area and shoot fresh weight. Root volume had positive and significant correlation to leaf area, shoot fresh weight, root fresh weight, and shoot dry weight. Related characters with plant biomass showed significant and positive correlation to leaf area and root volume (Table 3). Positive correlation indicates increasing of value in some characters will followed increasing of value in other related characters. Refer to Santos et al. (2018), leaf area has positive correlation to biomass characters. This result was related to positive correlation of root volume to biomass related characters. Correlation had related to sink and source of plant mechanism. Plant in drought condition will optimize sink and source to maintain of photoassimilate and related to adaptability response by physiological and morphological mechanism (Santos et al., 2018).

Refer to this result in Table 1 and Table 2, drought stress condition affected vegetative character, root system, and biomass character. Genotype which have high value on this characters can be selected as tolerant group in drought condition. This genotype can maintain metabolism and activity through drought condition. Sulawesi 3 x ICCRI 09 genotype showed high value almost in all characters. Wuriandani et al. (2019), showed 

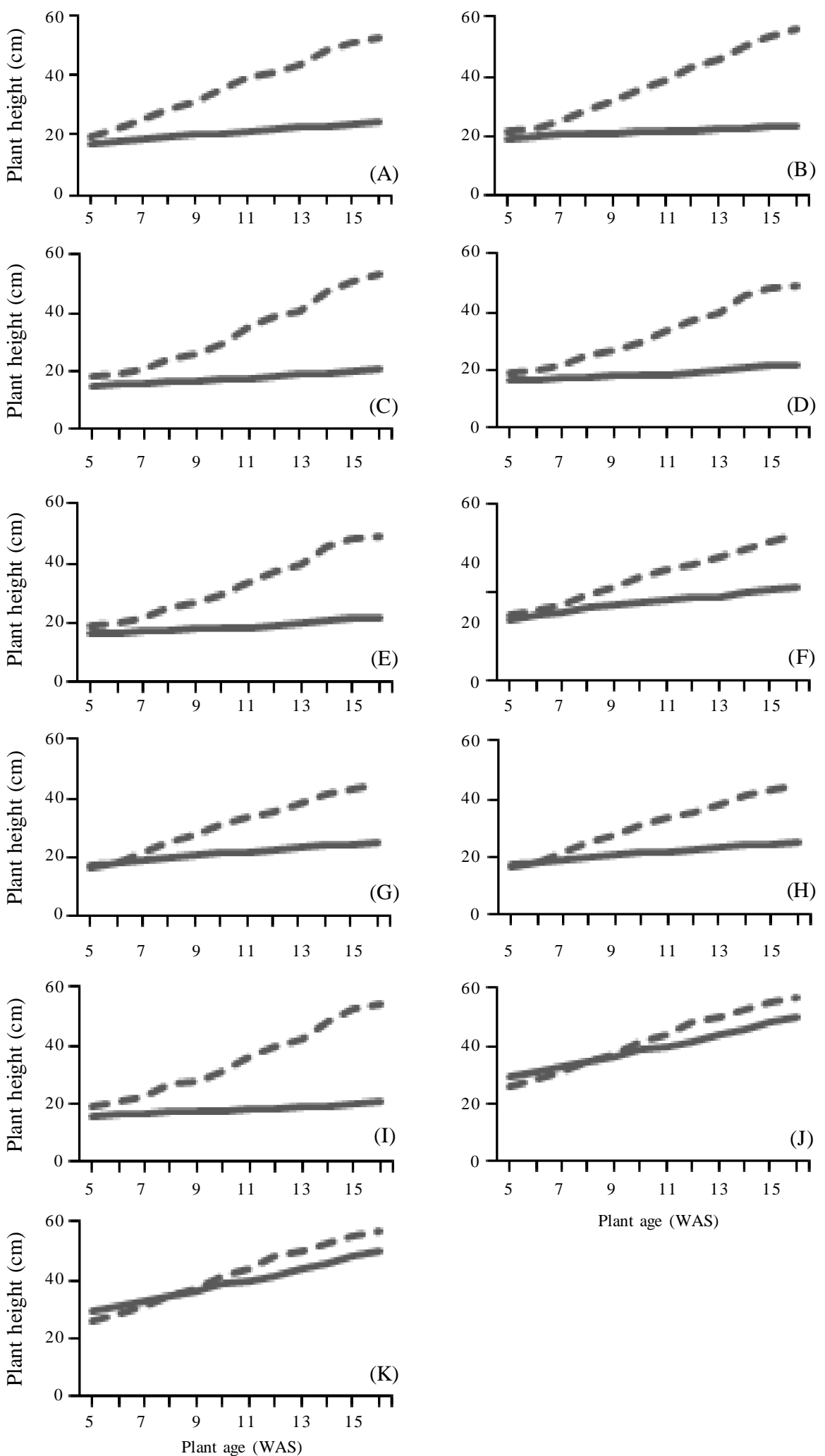

Figure 1. Plant height of cocoa on 5 WAS to 16 WAS; KW 516 (A), ICCRI 09 (B), Scavina 6 (C), Sulawesi 3 (D), TSH 858 (E), KW 516 x ICCRI 09 (F), KW 516 x Scavina 6 (G), Sulawesi 3 x ICCRI $09(\mathrm{H})$, Sulawesi 3 x Scavina 6 (I), TSH 858 x ICCRI 09 (J), TSH 858 x Scavina 6 (K) in $25 \%$ available water regime (-) and $100 \%$ available water regime (- $)$ 

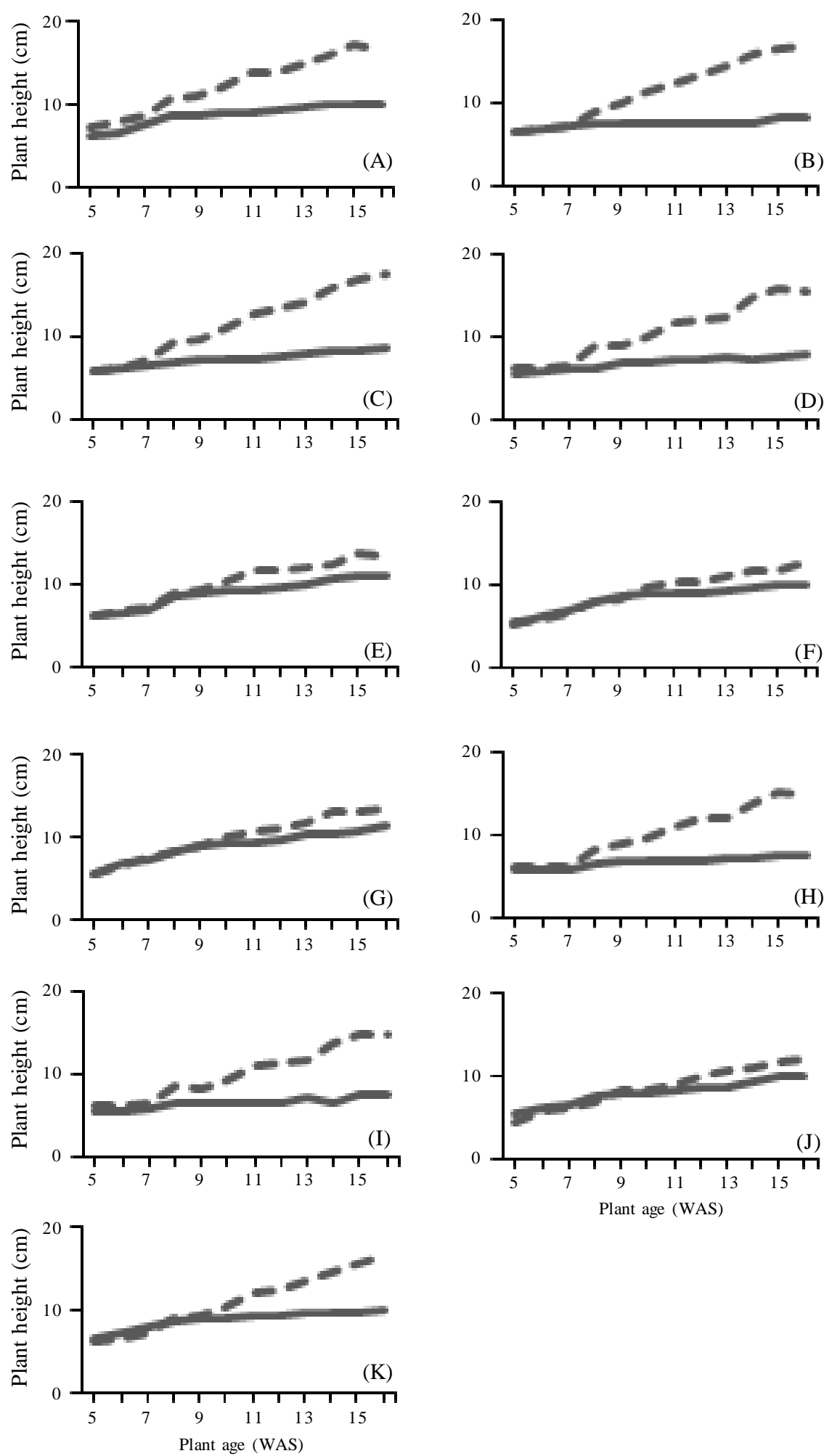

Figure 2. Number of leaves of cocoa on 5 WAS to 16 WAS. (A) KW 516, (B) ICCRI 09, (C) Scavina 6, (D) Sulawesi 3, (E) TSH 858, (F) KW 516 x ICCRI 09, (G) KW 516 x Scavina 6, (H) Sulawesi 3 x ICCRI 09, (I) Sulawesi 3 x Scavina 6, (J) TSH 858 x ICCRI 09, (K) TSH 858 x Scavina 6 in $25 \%$ available water regime (-) and $100 \%$ available water regime (- -) 


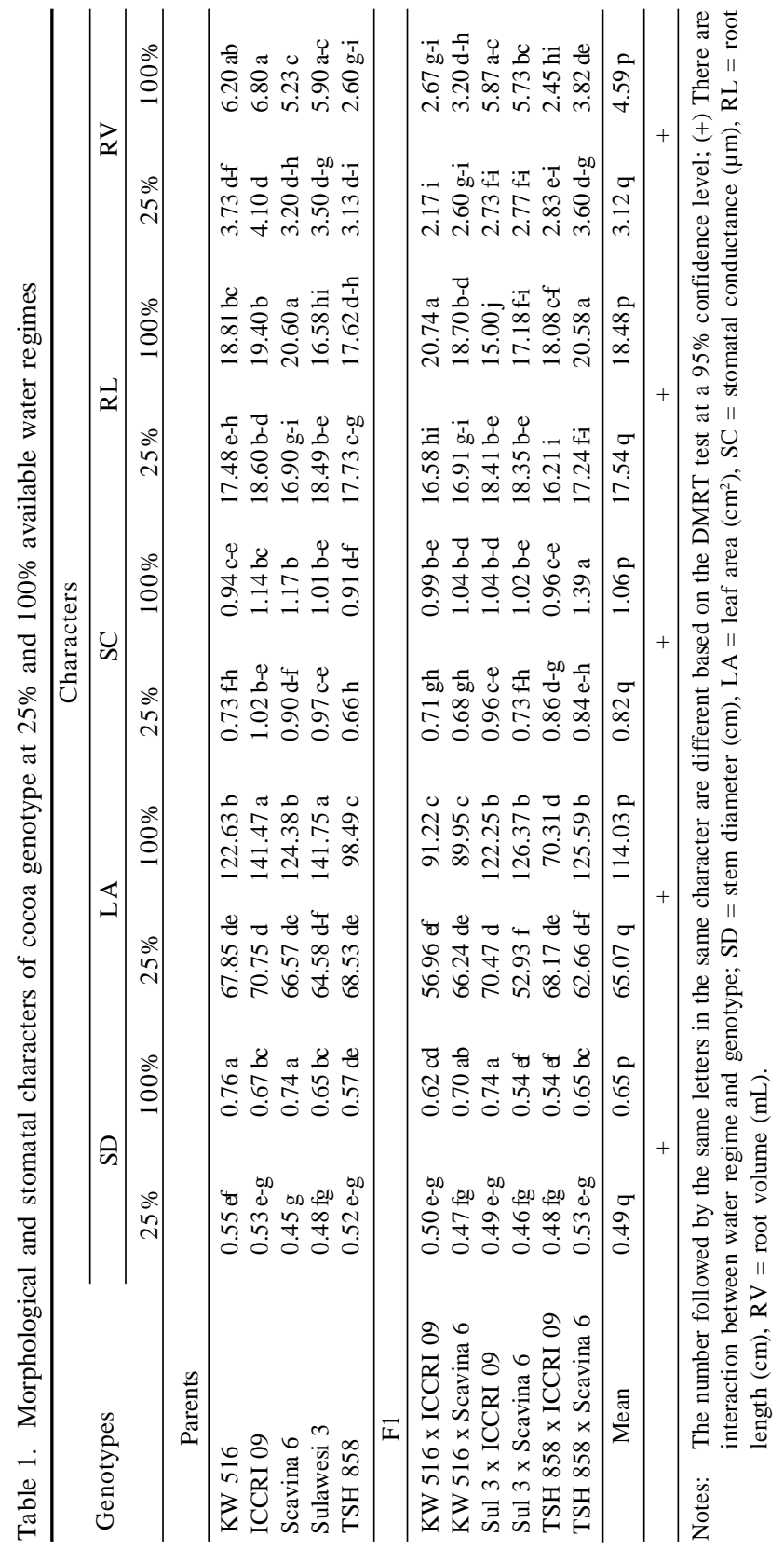




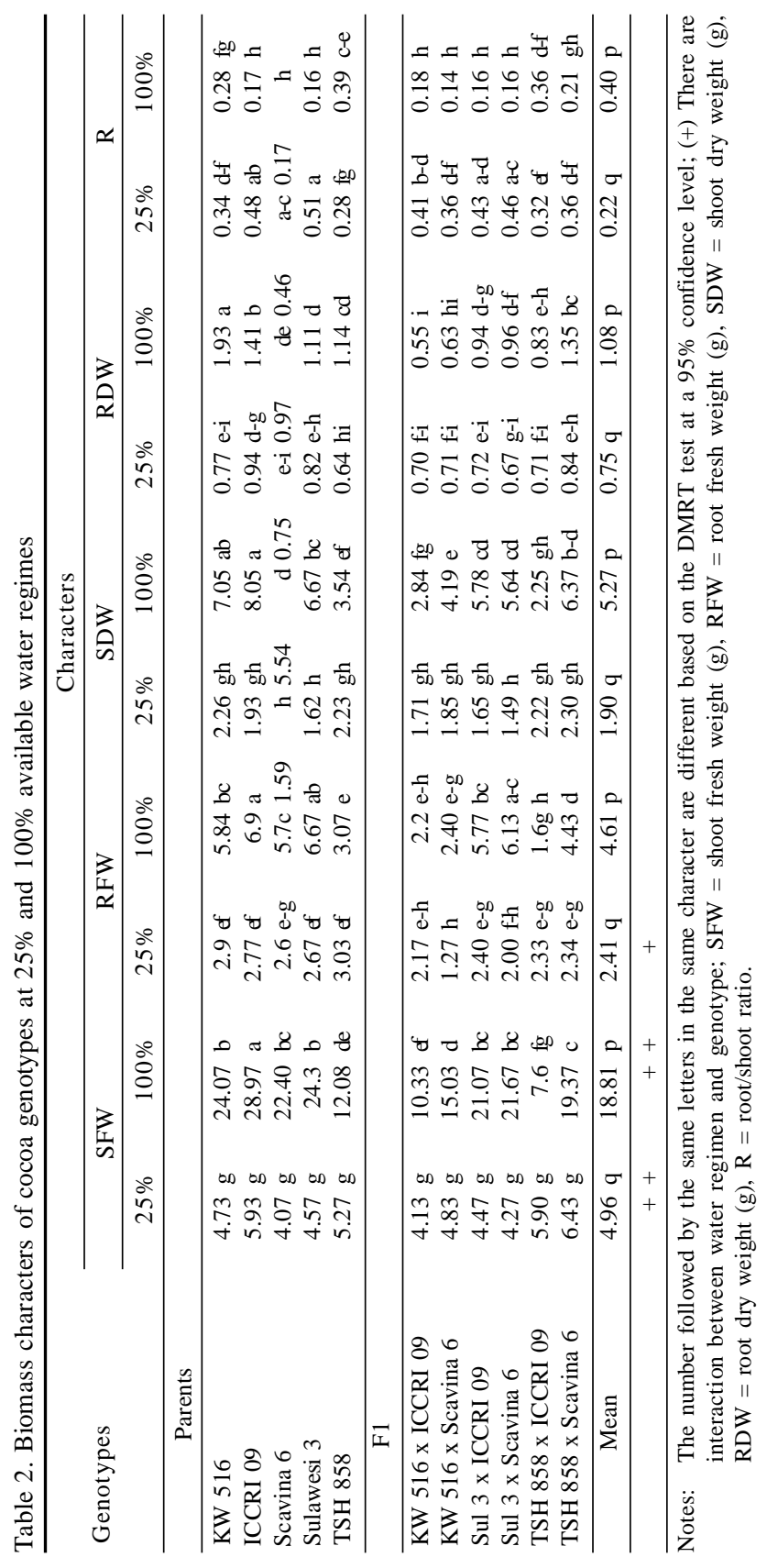


Table 3. Coefficient correlation between characters that observed on cocoa plant

\begin{tabular}{|c|c|c|c|c|c|c|c|c|c|c|}
\hline & SD & LA & $\mathrm{SC}$ & RL & RV & SFW & RFW & SDW & RDW & $\mathrm{R}$ \\
\hline SD & 1 & & & & & & & & & \\
\hline LA & $0.56^{\mathrm{ns}}$ & 1 & & & & & & & & \\
\hline $\mathrm{SC}$ & $0.34^{\mathrm{ns}}$ & $0.62 *$ & 1 & & & & & & & \\
\hline RL & $0.3^{\mathrm{ns}}$ & $0.25^{\mathrm{ns}}$ & $0.36^{\mathrm{ns}}$ & 1 & & & & & & \\
\hline $\mathrm{RV}$ & $0.544^{\mathrm{ns}}$ & $0.93 *$ & $0.5^{\mathrm{ns}}$ & $0.19^{\mathrm{ns}}$ & 1 & & & & & \\
\hline SFW & $0.56^{\mathrm{ns}}$ & $0.96 *$ & $0.6 *$ & $0.32^{\mathrm{ns}}$ & $0.97 *$ & 1 & & & & \\
\hline RFW & $0.43^{\text {ns }}$ & $0.95 *$ & $0.47^{\text {ns }}$ & $0.16^{\mathrm{ns}}$ & $0.95 *$ & $0.91 *$ & 1 & & & \\
\hline SDW & $0.64 *$ & $0.92 *$ & $0.57^{\text {ns }}$ & $0.36^{\mathrm{ns}}$ & $0.92 *$ & $0.96 *$ & $0.84 *$ & 1 & & \\
\hline RDW & $0.59^{\text {ns }}$ & $0.68 *$ & $0.32^{\mathrm{ns}}$ & $0.34^{\mathrm{ns}}$ & $0.75 *$ & $0.72 *$ & $0.69 *$ & $0.86 *$ & 1 & \\
\hline $\mathrm{R}$ & $-0.28^{\mathrm{ns}}$ & $0.18^{\mathrm{ns}}$ & $-0.01^{\mathrm{ns}}$ & $-0.1^{\mathrm{ns}}$ & $0.24^{\mathrm{ns}}$ & 0.09 ns & 0.37 ns & 0.05 ns & $0.28^{\mathrm{ns}}$ & 1 \\
\hline
\end{tabular}

Note: $\quad *$ There are positive correlation at a $95 \%$ confidence level, ${ }^{\text {ns }}$ there are no correlation at a $95 \%$ confidence; SD $=$ stem diameter, $\mathrm{LA}=$ leaf area, $\mathrm{RL}=$ root length, $\mathrm{RV}=$ root volume, $\mathrm{SC}=$ stomatal conductance, $\mathrm{SFW}=$ shoot fresh weight, RFW = root fresh weight, $\mathrm{SDW}=$ shoot dry weight, $\mathrm{RDW}=$ root dry weight, $\mathrm{R}=$ root $/$ shoot ratio.

that Sulawesi 3 x ICCRI 09 was moderate tolerance in drought condition.

The difference of genotype cahracter when tread by $100 \%$ available water compared to $25 \%$ available water could be used as parameters of the drought tolerance. The less the difference, the more tlerant the genotype to drought. Based on the criterium, the hybrid Sulawesi $3 \mathrm{x}$ ICCRI 09 has a high tolerance to drought.

\section{CONCLUSIONS}

Drought stress cause by decreasing values of morphological and stomatal characters. Root/ shoot ratio and stomatal conductance can be used to determine genotype with tolerant to drought. Sulawesi 3 x ICCRI 09 showed high values in root/shoot ratio and stomatal conductance. Sulawesi 3 x ICCRI 09 can be used as candidate of plant material tolerant to drought. Based on the less difference of genotype character when treated by $100 \%$ to $25 \%$ available water, Sulawesi 3 x ICCRI 09 is a potential hybrid with high tolerance to drought.

\section{REFERENCES}

Alban, M.K.A.; S.E. Apshara; K.B. Hebbar; T.G. Mathias \& A. Séverin (2015). Potential of antioxidant enzymes in depicting drought tolerance in cocoa (Theobroma cacao L.) genotypes at young age. African Journal of Science and Research, 4, 18-23.
Alban, M.K.A.; S.E. Apshara; K.B. Hebbar; T.G. Mathias \& A. Séverin (2016). Morpho-physiological criteria for assessment of two month old cocoa (Theobroma cacao L.) genotipes for drought tolerance. Indian Journal of Plant Physiology, 21, 23-30.

Ayegboyin, K.O. \& E.A. Akinrinde (2016). Effect of water deficit imposed during the early developmental phase on photosynthesis of cocoa (Theobroma cacao L.). Agricultural Science, 7, 11-19.

Azzeme, A.M.; S.N.A. Abdullah; M.A. Aziz \& P.E.M. Wahab (2016). Oil palm leaves and roots differ in physiological response, antioxidant enzyme activities and expression of stress-responsive genes upon exposure to drought stress. Acta Physiol Plant, 38, 1-12.

Beets, P.N.; S.H. Pearce; G.R Oliver \& P.W. Clinton (2007). Root/shoot ratios for deriving below-ground biomass of Pinus radiata stands. New Zealand Journal of Forestry Science, 37, 267-288.

Bunn, C.; T. Talsma; P. Laderach \& F. Castro (2017). Climate change impacts of Indonesian cocoa areas. CIAT.

Ditjenbun (2017). Statistik Perkebunana Indonesia 2015-2017, Kakao. Direktorat Jenderal Perkebunan, Jakarta.

ICCO (2017). Production of cocoa beans. ICCO Quarterly Bulletin of Cocoa Statistic. 43,1 .

Iryono (2010). Uji Ketahanan Stress Kekeringan Beberapa Klon Kakao pada Berbagai 
Jenis Media pada Pembibitan. Thesis. Universitas Negeri Jember. Jember.

Kurniawan, D. (2017). Pengaruh cekaman air terhadap pertumbuhan beberapa klon kakao (Theobroma cacao L.). Agroprimatech, 1, 18-25.

Maynard, G.H. \& D.M. Orcott (1987). The Physiology of Plants Under Stress. John Wiley and Sons, Inc, New York.

Medina, V. \& B. Laliberte (2017). A Review of Research on the Effects of Drought and Temperature Stress and Increased $\mathrm{CO}_{2}$ on Theobroma cacao L., and The Role of Genetic Diversity to Address Climate Change. CGIAR, Rome.

Ojo, A.D. \& I. Sadiq (2010). Effect of climate change on cocoa yield: a case of cocoa research institute (CRIN) farm, Oluyole local government Ibadan Oyo State. Journal of Sustainable Development in Africa, 12, 351-358.

Pirasteh-Anosheh, H.; A. Saed-Moucheshi; H. Pakniyat \& M. Pessarakli (2016). Stomatal responses to drought stress. In: Water Stress and Crop Plants: A Sustainable Approach, Vol. 1. John Wiley and Sons, Inc, New York.

Salehi-Lisar, S.Y. \& H. Bakhshayeshan-Agdam (2016). Drought stress in plants: Causes, consequences, and tolerance. In: Drought Stress Tolerance in Plants, Vol. 1. Springer, Switzerland.

Santos, I.C.; A.A.F. Almeida; A.S. Conceição; C.P. Pirovani; J.L Pires; R.R. Valle \& V.C. Baligar (2014). Molecular, physiological, and biochemical responses of Theobroma cacao L. genotypes to soil water deficit. Plos One, 9, 1-31.

Santos, E.A.; A.A.F. Almeida; D. Ahnert; M.C.S. Branco; R.R. Valle \& V.C. Baligar (2016). Diallel analysis and growth parameters as selection tools for drought tolerance in young Theobroma cacao plants. Plos One, 11, 1-22.
Santos, E.A.; A.A.F. Almeida; M.C.S. Branco; I.C. Santos; D. Ahnert; V.C Baligar \& R.R. Valle (2018). Path analysis of phenotypic traits in young cacao plants under drought conditions. Plos One, 13, 1-16.

Setyawan, B.; N. Puspitasari; A.W. Susilo \& I. Anita-Sari (2018). Rootstock characteristics of three combination of Theobroma cacao L. crosses on different water availability. Pelita Perkebunan, 34, 137-145.

Singh, R.K. \& B.D. Chaudhary (1985). Biometrical Methods in Quantitative Genetic Analysis. Kalyani Publisher, New Delhi.

Sobir; Miftahudin \& S. Helmi (2018). Respon morfologi dan fisiologi genotipe terung (Solanum melongena L.) terhadap cekaman salinitas. Jurnal Hortikultura Indonesia, 9, 131-138.

Towaha, J. \& E. Wardiana (2015). Evaluasi tingkat toleransi 35 genotipe kakao terhadap periode kering. Jurnal Tanaman Industri dan Penyegar, 2, 133-142.

Zakariyya, F.; B. Setyawan \& A.W. Susilo (2017). Stomatal, proline, and leaf water status characters of some cocoa clones (Theobroma cacao L.) on prolonged dry season. Pelita Perkebunan, 33, 109-117.

Zakariyya, F. \& D. Indradewa (2018). Drought stress affecting growth and some physiological characters of three cocoa clones at seedling phase. Pelita Perkebunan, 34, 156-165.

Wuriandani, A.; Sobir; D. Wirnas \& A.W. Susilo (2019). Genetic components estimation of F1 population of cocoa (Theobroma cacao L.) in drought stress condition. Pelita Perkebunan, 35, 85-93.

$* * 0 * *$ 